\title{
Article \\ Developing an Effective Peptide-Based Vaccine for COVID-19: Preliminary Studies in Mice Models
}

\author{
Haiqiang Yang ${ }^{1,+}$, Jessica Cao ${ }^{2,+}$, Xiaoyang Lin ${ }^{1}$, Jingwen Yue ${ }^{3,4}$, Tarek Zieneldien ${ }^{1}$, Janice Kim ${ }^{1}$, \\ Lianchun Wang ${ }^{3,4}$, Jianmin Fang ${ }^{5}$, Ruo-Pan Huang ${ }^{5}$, Yun Bai ${ }^{6}$, Kevin Sneed ${ }^{1}$ and Chuanhai Cao ${ }^{1, *}$
}

check for

updates

Citation: Yang, H.; Cao, J.; Lin, X.; Yue, J.; Zieneldien, T.; Kim, J.; Wang, L.; Fang, J.; Huang, R.-P.; Bai, Y.; et al. Developing an Effective

Peptide-Based Vaccine for COVID-19: Preliminary Studies in Mice Models. Viruses 2022, 14, 449. https:/ / doi.org/10.3390/v14030449

Academic Editor: Zoltan Vajo

Received: 21 January 2022

Accepted: 21 February 2022

Published: 22 February 2022

Publisher's Note: MDPI stays neutral with regard to jurisdictional claims in published maps and institutional affiliations.

Copyright: (C) 2022 by the authors. Licensee MDPI, Basel, Switzerland. This article is an open access article distributed under the terms and conditions of the Creative Commons Attribution (CC BY) license (https:// creativecommons.org/licenses/by/ $4.0 /)$.
1 Department of Pharmaceutical Sciences, Taneja College of Pharmacy, University of South Florida, Tampa, FL 33612, USA; haiqiangyang@usf.edu (H.Y.); xlin3@usf.edu (X.L.); tarekz@mail.usf.edu (T.Z.); janicekim1@usf.edu (J.K.); ksneed@usf.edu (K.S.)

2 Department of Kinesiology, Wiess School of Natural Sciences, Rice University, Houston, TX 77005, USA; jessica.a.cao@rice.edu

3 Byrd Alzheimer's Research Institute, Morsani College of Medicine, University of South Florida, Tampa, FL 33612, USA; yuejingwen@gmail.com (J.Y.); lianchunw@usf.edu (L.W.)

4 Department of Molecular Pharmacology and Physiology, Morsani School of Medicine, University of South Florida, Tampa, FL 33612, USA

5 RayBiotech Life, Inc., 3607 Parkway Lane Suite 200, Peachtree Corners, GA 30092, USA; david@raybiotech.com (J.F.); rhuang@raybiotech.com (R.-P.H.)

6 MegaNanoBioTech, Inc., 3802 Spectrum Blvd. Suite 122, Tampa, FL 33612, USA; ybai@megananobiotech.com

* Correspondence: ccao@usf.edu; Tel.: +1-813-396-0742

+ These authors contributed equally to this work.

\begin{abstract}
Coronavirus disease 2019 (COVID-19) has caused massive health and economic disasters worldwide. Although several vaccines have effectively slowed the spread of the virus, their longterm protection and effectiveness against viral variants are still uncertain. To address these potential shortcomings, this study proposes a peptide-based vaccine to prevent COVID-19. A total of 15 B cell epitopes of the wild-type severe acute respiratory coronavirus 2 (SARS-CoV-2) spike (S) protein were selected, and their HLA affinities predicted in silico. Peptides were divided into two groups and tested in C57BL/ 6 mice with either QS21 or $\mathrm{Al}(\mathrm{OH})_{3}$ as the adjuvant. Our results demonstrated that the peptide-based vaccine stimulated high and durable antibody responses in mice, with the $\mathrm{T}$ and B cell responses differing based on the type of adjuvant employed. Using epitope mapping, we showed that our peptide-based vaccine produced antibody patterns similar to those in COVID-19 convalescent individuals. Moreover, plasma from vaccinated mice and recovered COVID-19 humans had the same neutralizing activity when tested with a pseudo particle assay. Our data indicate that this adjuvant peptide-based vaccine can generate sustainable and effective $\mathrm{B}$ and $\mathrm{T}$ cell responses. Thus, we believe that our peptide-based vaccine can be a safe and effective vaccine against COVID-19, particularly because of the flexibility of including new peptides to prevent emerging SARS-CoV-2 variants and avoiding unwanted autoimmune responses.
\end{abstract}

Keywords: COVID-19; peptide; spike protein; vaccine; adjuvant; T and B cells; neutralizing activity

\section{Introduction}

Coronavirus disease 2019 (COVID-19) is caused by the severe acute respiratory coronavirus 2 (SARS-CoV-2), which is a single-strand positive RNA virus that enables the host cell to directly synthesize proteins upon viral entry and uncoating [1]. This enables viral replication and the rate of viral spread to occur much more rapidly than other types of viruses [2]. Given this alarming rate of transmission, many countries were unable to implement an effective and timely approach to curb the spread of the virus, and the worldwide economic impacts of COVID-19 have been historically devastating [3].

Other viral outbreaks, such as SARS-CoV and Middle East respiratory syndrome coronavirus (MERS-CoV), have led to the development of several treatment strategies [4-6]. Drugs 
such as Nafamostat, Camostat, Chloroquine, Imatinib, Hydroxychloroquine, Ivermectin, and Remdesivir have either been studied, evaluated, or have received limited approvals by the U.S. Food and Drug Administration (FDA) to treat severe cases of COVID-19 [4,7]. Infected patients have also been treated with convalescent sera, purified antibodies from sera, or generated monoclonal antibodies from patients [8,9]. While these methods are effective, they are not viable large-scale solutions, since resources for convalescent sera therapy are limited, and producing monoclonal antibodies is time consuming and expensive [9-14].

The most effective approach to combat infectious disease is through prevention using vaccines. Vaccines have led to the eradication of smallpox, the near-elimination of poliomyelitis, and the prevention of hepatitis B (HBV) and human papillomavirus (HPV) [15-19]. There are four general vaccine types for preventing viral infections: (I) "classic" vaccines that utilize inactivated or attenuated whole virus [20,21], (II) nucleic acid vaccines (DNA and RNA) that elicit the host to produce antigenic fragments of the virus [22], (III) subunit vaccines that use recombinant proteins or synthetic peptides representing antigenic fragments of the virus [22], and (IV) viral vector-based vaccines that utilize viral vectors to deliver genetic material to host cells $[20,23]$. COVID-19 vaccines that have been approved by the U.S. FDA include classic inactivated viral particle vaccines, RNA-based vaccines, subunit-based (recombinant $S$ protein) vaccines, and viral vector-delivered vaccines [24-33].

Coronaviruses enter host cells by binding to a cell surface receptor for viral attachment, then entering endosomes, and eventually fusing viral and lysosomal membranes [34]. This entry process is mediated by a virus surface-anchored spike (S) protein [35]. For mature viruses, the $S$ protein is present as a trimer, with three receptor-binding $S 1$ heads sitting on top of a trimeric membrane fusion S2 stalk [36]. The receptor-binding domain (RBD) on S1 specifically recognizes angiotensin-converting enzyme 2 (ACE2) as its receptor [37]. The SARS-CoV-2 spike protein needs to be proteolytically activated at the S1/S2 boundary to fuse membranes, such that S1 dissociates and S2 undergoes a dramatic structural change [38]. These SARS-CoV-2 entry-activating proteases include cell surface protease TMPRSS2 and lysosomal proteases cathepsins [39]. In general, the RBD domain on the $S$ protein of SARS-CoV-2 serves as a ligand for ACE2, and ACE2 is broadly found throughout the human body [40]. Consequently, SARS-CoV-2 can quickly spread throughout the human body through binding to the ACE2 receptor [41].

COVID-19 continues to have devastating effects on public health, particularly through the occurrence of viral variants [42-45]. Some individuals who have completed the vaccine series (i.e., two doses and a booster) are still at risk of contracting COVID-19 through breakthrough infections, and those who have caught COVID-19 can also become re-infected by SARS-CoV-2 [46,47]. These infections are caused, in part, by the lack of herd immunity, but primarily because of viral mutations. Significantly decreased neutralizing potency has also been observed from the vaccines against B.1.1.7 isolate (2-fold), E484K/N501Y/D614G recombinant variant (four-fold), and two chimeric SARS-CoV-2 strains encoding B.1.351 spike (10-fold) and P.1 spike (2.2-fold) compared to the D614G variant in Vero-hACE2-TMPRSS2 cells [48]. With breakthrough infections and re-infections becoming more common, current vaccines are facing a considerable challenge in preventing the spread of COVID-19.

Understanding the advantages and disadvantages of each vaccine strategy is imperative in developing a safe and effective COVID-19 vaccine. Effective vaccines for infectious diseases ultimately require both $\mathrm{T}$ and $\mathrm{B}$ cell responses; an adjuvant is also required to prime the nonspecific immune system and ensure the robustness and duration of an immune response $[49,50]$. However, a vaccine with an adjuvant often might not be suitable for those with impaired immune systems (e.g., the elderly), since adjuvants can over prime the immune system [51,52]. Furthermore, age can impair immunity, so older individuals may exhibit anergy in the immune response. COVID-19 has also caused higher death rates among older populations, so a vaccine that can protect this population is crucial. Thus, each vaccine should be designed and tailored for its intended population (i.e., "personalized medicine" ${ }^{\prime \prime}$. As such, aged mice were utilized to provide a more thorough understanding of how the vaccine adjuvants may impact impaired immune systems. 
While DNA vaccines can elicit a good T cell response, the B cell response is relatively low compared to protein-based vaccines [53-56]. Alternatively, mRNA-based vaccines are a novel approach for infectious diseases and are currently the dominant approach in fighting COVID-19 [57]. However, it remains unclear as to how effective they are in stimulating T cell and B cell responses in comparison to a more traditional protein-based vaccine or to natural infection.

Here, we developed a peptide-based vaccine for COVID-19 prevention. There are four primary advantages of peptide-based vaccines: (1) large-scale peptide synthesis is relatively inexpensive and the technology is well-established, (2) peptides can fold into three-dimensional epitopes capable of inducing antibody responses to linear and conformational structures, (3) unique epitopes can be selected to avoid autoimmune responses that could be generated by the whole protein, and (4) new epitopes can be easily added to the peptide mixture as new viral mutations are identified [58-60].

\section{Materials and Methods}

\subsection{Antigen and Cell Selection}

The SARS-CoV-2 spike (S) protein of the wild-type "Wuhan" strain (Accession: YP_009724390.1) was submitted to DNAStar (Madison, WI, USA) for in silico antigen (peptide) identification. Nine epitopes were selected from the S protein's subunit 1 (S1) domain, and six sequences were selected from the subunit 2 (S2) domain. The selected peptide sequences were submitted to GenBank for homology analysis, which confirmed that the peptides were unique. Peptide antigenicity was confirmed by DNAStar.

Human Leukocyte Antigen-I (HLA-I), Mouse Major Histocompatibility Complex-I (MHC-I), and HLA-II affinity analyses were conducted with the T Cell Epitope Prediction Tools, using the Immune Epitope Database (IEBD) Analysis Resource at http:/ / tools.iedb. $\mathrm{org} / \mathrm{main} / \mathrm{tcell} /$, accessed on 21 July 2021. The specificity of the peptides to SARS-CoV-2 were confirmed using the protein BLAST module at https://blast.ncbi.nlm.nih.gov/Blast. cgi, accessed on 21 July 2021. All peptides were provided by Biomer Technology Inc. (Pleasanton, CA, USA).

\subsection{SARS-CoV-2 Pseudovirus System Selection}

The SARS-CoV-2 pseudovirus system was provided by Dr. Lianchun Wang's lab at USF. A SARS-CoV-2 spike open reading frame (ORF) mammalian expression plasmid was obtained from Addgene (Plasmid \#145032; Watertown, MA, USA). NL4-3 mCherry Luciferase, a replication-defective HIV dual reporter vector expressing mCherry and firefly luciferase, was obtained from Addgene (Plasmid \#44965). Lipofectamine ${ }^{\mathrm{TM}} 3000$ Transfection Reagent was purchased from Invitrogen (Waltham, MA, USA). The human 293T embryonic kidney cell line was obtained from the American-Type Culture Collection (ATCC) (Manassas, VA, USA). The 293T-ACE2-GFP cell line was established by transfecting 293T cells with the ACE2-GFP expression vector (OriGene; Rockville, MD, USA). Both cell lines were maintained in Dulbecco's modified Eagle's medium (DMEM) with 2 mM L-glutamine, 10\% FBS, $100 \mu \mathrm{g} / \mathrm{mL}$ streptomycin, and $100 \mathrm{IU} / \mathrm{mL}$ penicillin. Lentiviral vector particles concentration reagent Lenti- $\chi^{\mathrm{TM}}$ Concentrator was purchased from TaKaRa (Mountain View, CA, USA). The Luciferase Assay System was purchased from Promega (Madison, WI, USA).

For SARS-CoV-2 pseudovirus production, $4 \times 10^{6} 293 \mathrm{~T}$ cells were seeded in a $100 \mathrm{~mm}$ cell culture dish. After 48 h, $10 \mu \mathrm{g}$ NL4-3 mCherry Luciferase plasmid and $10 \mu \mathrm{g}$ SARSCoV-2 spike plasmid were mixed in $1.5 \mathrm{~mL}$ Opti-MEM medium and incubated at RT for $5 \mathrm{~min}$. Then, $65 \mu \mathrm{L}$ of Lipo3000 was mixed in $1.5 \mathrm{~mL}$ Opti-MEM medium at RT for $5 \mathrm{~min}$, and the plasmid mixture was then mixed with the Lipo3000 mixture and incubated at RT for $20 \mathrm{~min}$. The mixture was added dropwise into a dish and incubated in the cell culture incubator. After $48 \mathrm{~h}$, cells were centrifuged at $500 \times g$ for $10 \mathrm{~min}$, cell supernatant was collected, and $9 \mathrm{~mL}$ of supernatant was transferred into a separate tube with a $3 \mathrm{~mL}$ Lenti-X concentrator. The supernatant was stored at $4{ }^{\circ} \mathrm{C}$ for $4 \mathrm{~h}$ and centrifuged at $1500 \times g$ for 
$45 \mathrm{~min}$. The supernatant was aspirated, and the precipitate was resuspended with $90 \mu \mathrm{L}$ cold DPBS and then frozen at $-80{ }^{\circ} \mathrm{C}$.

\subsection{Mice}

C57BL/ 6 mice were used for this study. The mice were 6 months old, gender balanced in each group, and housed at the animal facility at the University of South Florida (USF) Health Center. All animal experiments were approved (IS00008370) by the Institutional Animal Care and Use Committee (IACUC) at USF and performed according to the National Institute of Health (NIH) guidelines.

\subsection{Vaccine Preparation}

The peptides were split into two groups by $S$ protein subdomain; each group contained peptides with high affinity to MHC (HLA) class I and class II to ensure that the peptide mixture would cover most MHC typing. HLA-I was predicted against all available allele types, and the top $1 \%$ was considered high affinity. HLA-II was also tested against all allele types in the database, and the selected standard was set at 10\% rank as recommended.

A total of 15 peptides were identified against the $S$ protein. Each peptide was dissolved with DMSO at $50 \mathrm{mg} / \mathrm{mL}$, grouped into two groups, and mixed at $50 \mu \mathrm{g}$ each. The two most commonly utilized adjuvants-QS21 and $\mathrm{Al}(\mathrm{OH})_{3}(0.4 \%$ Alhydrogel from InvivoGen (Cat no\# vac-alu-50, San Diego, CA, USA) - were selected for the vaccine formula. QS21 was purchased from Desert King International (San Diego, CA, USA), and $\mathrm{Al}(\mathrm{OH})_{3}$ was purchased from Invitrogen (Waltham, MA, USA). Common adjuvants include $\mathrm{Al}(\mathrm{OH})_{3}$, which can promote earlier antibody production, and QS21, which promotes the release of Th1 cytokines participating in the elimination of intracellular pathogens [61-63]. The concentration of adjuvant is $25 \mu \mathrm{g}$ per dose.

\subsection{Vaccination and Sample Collection}

Two total studies were conducted in this report, with peptide mixture groups 1 and 2 using different groups of mice. Group 1 mice (C57BL/6) were 6 months old and injected with A1-G1 (8 peptides); group 2 mice were 8 months old and received H1-E2 (7 peptides) at equal mixture amounts (50 $\mu \mathrm{g} /$ peptide) with either $\mathrm{QS} 21$ or $\mathrm{Al}(\mathrm{OH})_{3}$ as the adjuvant via bi-weekly subcutaneous injections for 6 injections.

Blood samples were obtained with EDTA vacutainer tubes 7 days after each injection, starting from the 2 nd injection. Additionally, $50 \mu \mathrm{L}$ of whole blood was taken for flow cytometry analysis and the rest of the blood was centrifuged at $300 \times g$ for $5 \mathrm{~min}$. Plasma was then transferred into a new tube and stored at $-80^{\circ} \mathrm{C}$ for future application. The immunization and blood drawing schedule was conducted as shown in Scheme 1.

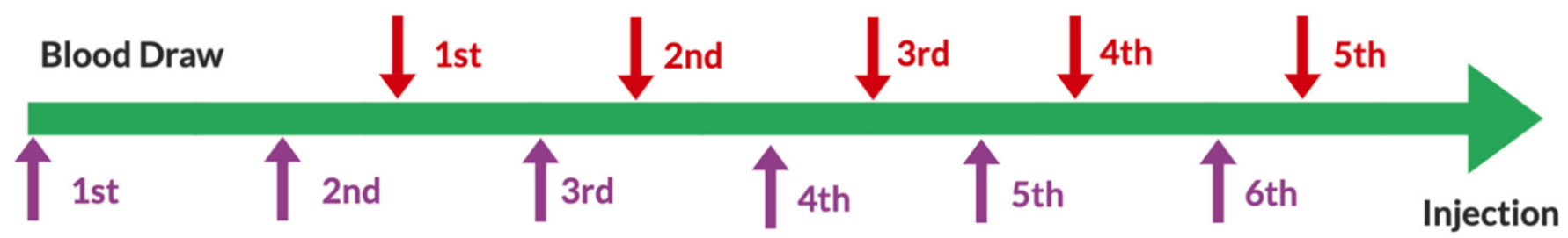

Scheme 1. Time schedule of vaccination and blood collection for the C57BL6 mice.

\subsection{Indirect ELISA}

The SARS-CoV-2 S protein's full length S1 (Cat\#230-30161) and receptor binding domain (RBD) (Cat\#230-30162) recombinant proteins expressed in human HEK293 cells were purchased from RayBiotech Life, Inc. (Peachtree Corners, GA, USA). The SARS-CoV2 S protein's S1 (Cat\#230-01101) and S2 (Cat\#230-01103) subunit recombinant proteins expressed in E. coli were also purchased from RayBiotech Life, Inc.

Immulon 4 HBX 96-well plates (Cat\# 3855) were purchased from Thermo Fisher Scientific (Waltham, MA, USA). HRP conjugated anti-Mouse IgG antibodies were ordered 
from SouthernBiotech (Birmingham, AL, USA; cat no. 1030-05), and HRP-conjugated anti-Human IgG antibodies were ordered from SouthernBiotech (Cat: 2015-05). Human plasma was purchased from RayBiotech Life, Inc.

An indirect ELISA was conducted to measure antibody response. First, 96-well plates were coated with $50 \mu \mathrm{L}$ of peptides from $10 \mu \mathrm{g} / \mathrm{mL} \mathrm{S1}$ and S2 and $1 \mu \mathrm{g} / \mathrm{mL}$ recombinant protein. The plates were washed 4 times with PBST, $180 \mu \mathrm{L} /$ well of $0.05 \%$ BSA buffer was added, and the plates were incubated at $37^{\circ} \mathrm{C}$ for $1 \mathrm{~h}$. The plates were then washed with $1 \times$ wash buffer, and diluted plasma was added to each well at 1:200, 1:800, and 1:3200-fold dilutions and incubated for $1 \mathrm{~h}$ at room temperature (RT). Anti-human or anti-mouse HRP-conjugated antibodies were then added at 1:10,000 dilutions, incubated for $1 \mathrm{~h}$ at RT, and washed with $1 \times$ wash buffer. Then, $100 \mu \mathrm{L}$ of TMB substrate was added, followed by $0.4 \mathrm{M}$ sulfuric acid to stop the reaction. Plates were read at OD450, with OD650 as the reference.

For epitope mapping of mouse and human plasma, plasma was added to the antigencoated 96-well ELISA plate for indirect ELISA as described above at 1:200, 1:800, and 1:3200-fold dilutions and incubated for $1 \mathrm{~h}$ at RT.

\section{7. $T$ Cell Detection}

T cell population detection post vaccination was assessed using flow cytometry assay and $50 \mu \mathrm{L}$ whole EDTA blood. Red blood cells were lysed with ACK buffer and washed twice with $1 \%(v / v)$ FBS in $1 \times$ PBS. The fluorophore-conjugated antibody mixture was added to the sample and incubated on ice for $20 \mathrm{~min}$. FITC anti-mouse CD3 $\varepsilon$ Antibody (Cat\#10036), APC/Cyanine7 anti-mouse CD8a Antibody (Cat\#100714), APC anti-mouse CD4 Antibody (Cat\#100412), and PE anti-mouse CD19 Antibody (Cat\#115508) were bought from Biolegend (San Diego, CA, USA). Cells were then resuspended with 1\% FBS in $1 \times$ PBS after washing 3 times. All samples were run on the flow cytometer.

\subsection{Neutralization Assay}

ACE2-293T-GFP cells were seeded into a poly-lysine-coated 96-well plate at a density of $1.2 \times 10^{4}$ cells/well. After $24 \mathrm{~h}, 6 \mu \mathrm{L}$ of SARS-CoV-2 pseudovirus and diluted human plasma or mouse samples were added at the designated dilutions, and the medium was changed after $6 \mathrm{~h}$ of incubation. The plates were incubated in a $\mathrm{CO}_{2}$ incubator for $48 \mathrm{~h}$, the medium was removed, and the cells were washed with Hank's balanced salt solution (HBSS). HBSS was aspirated and $20 \mu \mathrm{L}$ of Promega lysis buffer was added at RT for $5 \mathrm{~min}$. Luminescence was measured after adding $50 \mu \mathrm{L}$ of Luciferase substrate into $20 \mu \mathrm{L}$ of lysis buffer.

\subsection{Immunoglobulin Isotyping}

The mouse immunoglobulin isotyping (Cat\#MGAMMAG-300K) and cytokine magnetic bead panel assay (Cat\#MCYTOMAG-70K) were purchased from MilliporeSigma (Burlington, MA, USA).

First, $100 \mu \mathrm{L}$ of assay buffer was added to each well of the assay plate and mixed on a plate shaker for $10 \mathrm{~min}$ at RT. The assay buffer was then discarded, and the remaining residue was removed from the wells by inverting the plate and tapping it numerous times on an absorbent towel. Then, $50 \mu \mathrm{L}$ of the assay buffer was added to the background wells, and $50 \mu \mathrm{L}$ of the standard, control, and diluted samples were added to the appropriate wells. Afterwards, the MILLIPLEX MAP Anti-Mouse Multi-Immunoglobulin beads were vortexed at medium speed for $15 \mathrm{~s}$ and sonicated for $15 \mathrm{~s}$ using a sonication bath. Then, $25 \mu \mathrm{L}$ of the bead solution was added into each well, and the plate was covered and incubated on a plate shaker for $15 \mathrm{~min}$ at RT. The plate was then washed twice with $200 \mu \mathrm{L} /$ well of washing buffer. After washing, $25 \mu \mathrm{L}$ /well of prepared Anti-Mouse $\mathrm{k}$ Light Chain PE was added, covered, and incubated on a plate shaker at RT for $15 \mathrm{~min}$. Finally, the fluid was aspirated, and beads were resuspended in $150 \mu \mathrm{L} /$ well of sheath fluid. The plate was then read on the Bio-Rad Bio-Plex MAGPIX Multiplex Reader. 


\subsection{Cytokine Detection with Multiplex Assay}

First, $200 \mu \mathrm{L}$ of washing buffer was added to each well, and the plate was sealed and incubated on the plate shaker for $10 \mathrm{~min}$ at RT. The wash buffer was then aspirated, and $25 \mu \mathrm{L}$ of each standard or control was introduced into the appropriate wells, with the assay buffer utilized for the $0 \mathrm{pg} / \mathrm{mL}$ standard (background). Then, $25 \mu \mathrm{L}$ of the assay buffer was added to the sample wells, and $25 \mu \mathrm{L}$ of the serum matrix solution was added to the background, standard, and control wells. Afterwards, $25 \mu \mathrm{L}$ of the diluted samples were introduced into the appropriate wells. Then, the mixing bottle was vortexed, and $25 \mu \mathrm{L}$ of the mixed or premixed beads were added to each well and shaken for $10 \mathrm{~min}$ at RT. The plate was then sealed with a plate sealer, wrapped with aluminum foil, and incubated on a plate shaker overnight at $2-8{ }^{\circ} \mathrm{C}$. The following day, well contents were gently removed, and the plate was washed twice. Then, $25 \mu \mathrm{L}$ of the detection antibodies were added into each well and incubated on a plate shaker for $1 \mathrm{~h}$ at RT. The well contents were removed, the plates were washed twice, and $150 \mu \mathrm{L}$ of sheath fluid was added to all wells. The beads were then resuspended on a plate shaker for $5 \mathrm{~min}$, and the plate was read on the Bio-Rad Bio-Plex MAGPIX Multiplex Reader.

\section{Results}

\subsection{Selection of SARS-CoV-2 Peptides}

Sixteen peptides were predicted to have high antigenicity with $100 \%$ homology to the SARS-CoV-2 virus were split across two peptide mixtures (Group 1, Group 2) that covered all Class I and II allele types of C57B/6 mice. The peptide sequences and T cell epitope results are listed in Table 1 and Supplementary Table S1, respectively.

Table 1. Peptide sequence and their usage in the vaccination. A1-F2 are the peptide sequence names of each selected peptide. A cystine is added to the N-terminal of each peptide; AA position is the amino acid position in the whole $S$ protein; vaccine group indicates the peptide mixture used for the vaccine.

\begin{tabular}{cccc}
\hline Sequence Name & Peptide Sequence & AA Position in S Protein & Vaccine Group \\
\hline A1 & CLPFQQFGRDIADTTDAVRDPQTLEIL & $\mathbf{5 6 0 - 5 8 5}$ & Group1 (S1) \\
B1 & CYFKIYSKHTPINLVRDLPQ & $\mathbf{2 0 0 - 2 1 8}$ & Group1 (S1) \\
C1 & CGVYYHKNNKSWMESEFRVY & $\mathbf{1 4 2 - 1 6 0}$ & Group1 (S1) \\
D1 & CFHAIHVSGTNGTKRFDNPVLPF & $\mathbf{6 5 - 8 6}$ & Group1 (S1) \\
E1 & CTRGVYYPDKVFRSSVLHS & $\mathbf{3 3 - 5 0}$ & Group1 (S1) \\
F1 & CYQTQTNSPRRARSVAS & $\mathbf{6 7 4 - 6 8 9}$ & Group1 (S1) \\
G1 & CVIAWNSNNLDSKVGGNY & $\mathbf{4 4 3 - 4 4 9}$ & Group1 (S1) \\
H1 & CALDPLSETKCTLKSFTVEKGIYQTSNFRV & $\mathbf{2 9 1 - 3 2 0}$ & Group2 (S1) \\
I1 & CATVCGPKKSTNLVKNKCVNFNFNG & $\mathbf{5 2 2 - 5 4 5}$ & Group2 (S1) \\
J1 & CYNYLYRLFRKSNLKPFERDISTEIYQA & $\mathbf{4 5 2 - 4 7 6}$ & Group2 (S1) \\
A2 & CIAVEQDKNTQEVFAQV & $\mathbf{7 7 0 - 7 8 3}$ & Group2 (S2) \\
B2 & CKQIYKTPPIKDFGGFNFSQILPDPSKPSKRSFIEDLL & $\mathbf{7 8 6 - 8 2 2}$ & Group2 (S2) \\
C2 & CNSAIGKIQDSLSSTASAL & $\mathbf{9 2 7 - 9 4 5}$ & Group2 (S2) \\
D2 & CPLQPELDSFKEELDKYFKNHTSPDVDLGDIS & $\mathbf{1 1 4 1 - 1 1 7 1}$ & Group2 (S2) \\
E2 & CVPAQEKNFTTAPAICHDGKAHFPREGVFVSNGTHWF & $\mathbf{1 0 6 8 - 1 1 0 3}$ & Group2 (S2) \\
F2 & CMTSCCSCLKGCCSCGSCCKFDEDDSEPVLKGV & $\mathbf{1 2 3 6 - 1 2 6 7}$ & Group2 (S2) \\
\hline
\end{tabular}

\subsection{Antibody Response Post Vaccination Using Group 1 Peptides with Different Adjuvants}

First, $50 \mathrm{ug} /$ peptide of peptides A-G of the S1 protein were mixed with either the QS21 or $\mathrm{Al}(\mathrm{OH})_{3}$ adjuvant and injected into mice subcutaneously at two-week intervals. Blood was collected 10 days after each injection and used for antibody detection. It is evident that, after two injections, both groups could detect an antibody response, but the $\mathrm{Al}(\mathrm{OH})_{3}$ group exhibited a higher antibody response than the QS21 group. With continuous boosting, antibody response to each peptide differed between the two adjuvants (Figure 1). 

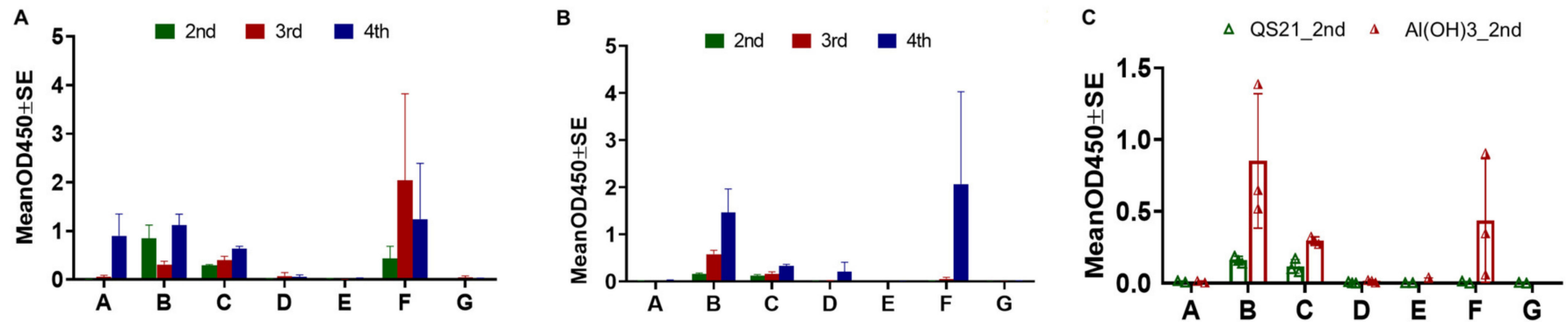

Figure 1. Antibody response post-vaccination tested by ELISA. Test subjects (mice) were divided into 2 groups ( $n=3$ per group): one group received the peptide mixture 1 (mainly S1) with QS21 as the adjuvant, and the other group received the peptide mixture 1 with $\mathrm{Al}(\mathrm{OH})_{3}$ as the adjuvant. There were a total of 6 inoculations at 2-week intervals and 5 time points where blood samples were collected. Plasma was analyzed by ELISA with peptide A1-G1-coated plates. In total, 3 time points were selected for comparison. (A) shows the results of the 3 mice that received the $\mathrm{Al}(\mathrm{OH})_{3}$ adjuvant, (B) the results of the three mice with QS21 as adjuvant, and $(\mathrm{C})$ is the comparison of blood post 2nd vaccination. There are significant antibodies in both adjuvant groups against peptides $\mathrm{B}(p=0.0058<0.01)$ and $\mathrm{F}(p=0.0009<0.01)(\mathrm{C})$. No antibodies were induced against peptides $\mathrm{A}, \mathrm{D}, \mathrm{E}$, or $\mathrm{G}$ after 2 vaccinations.

\subsection{Antibody Response to Group 2 Peptides with Different Adjuvants}

After the Group 1 peptide test, another group of peptides were injected into mice, with either QS21 or $\mathrm{Al}(\mathrm{OH})_{3}$ adjuvants. There were a total seven peptides in this group-two in the S1 domain and five in the S2 domain. The ELISA results showed that antibodies were produced against five peptides in both QS21 and $\mathrm{Al}(\mathrm{OH})_{3}$ groups but were relatively lower in the QS21 group than the $\mathrm{Al}(\mathrm{OH})_{3}$ adjuvant group; $\mathrm{Al}(\mathrm{OH})_{3}-2 \mathrm{D}$ produce higher antibodies than the QS21 adjuvant group $(p<0.001)$. No antibodies were induced against peptide $2 \mathrm{~A}$ and $1 \mathrm{~J}$ after two injections (Figure 2).

$\Delta$ QS21 $\Delta \mathrm{AL}(\mathrm{OH}) 3 \quad 0 \mathrm{Ctr}$

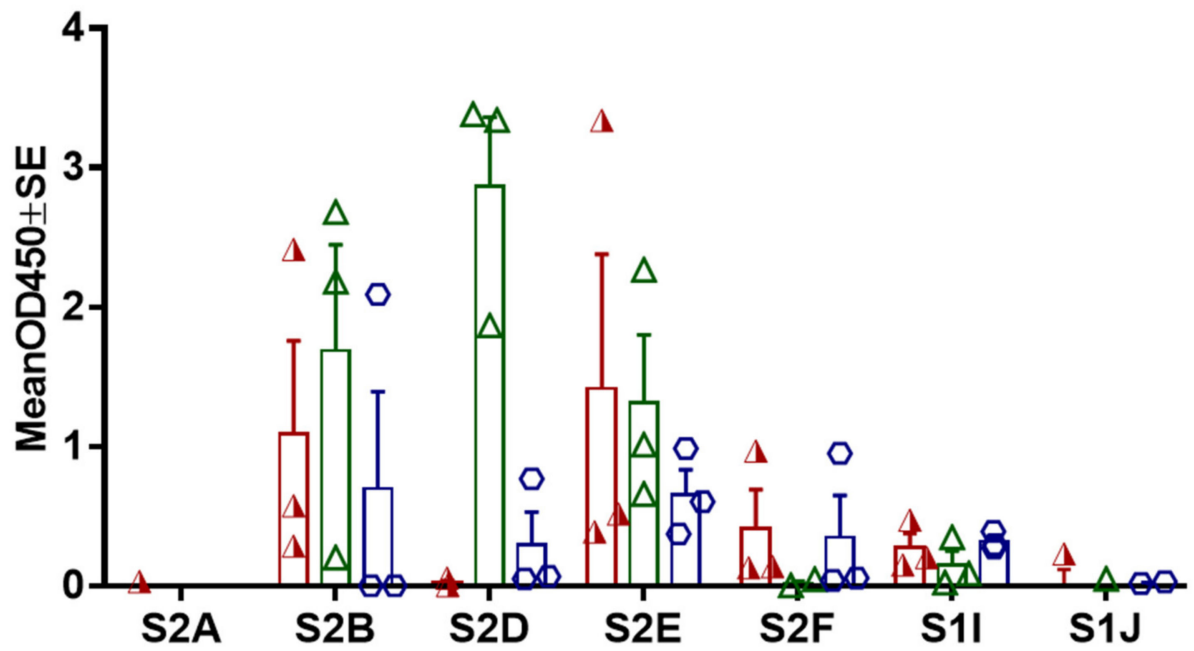

Figure 2. Antibody response to peptide mixture after 2 vaccines. In total, 7 peptides were used in this injection, with either QS21 or $\mathrm{Al}(\mathrm{OH})_{3}$ as adjuvants. Peptides S1I and S1J are selected from S1 domain. Peptide S2A, S2B, S2D, S2E and S2F are selected from S2 domain. ( $\mathrm{N}=3, p<0.001)$.

\subsection{The Similarity of Epitope Mapping between Recovered Human Sera and Vaccinated} Mouse Sera

Four mice plasma (two from each peptide mixture group) and four human plasma samples (two recovered patient blood and two from our tissue bank collected in 2008 as negative controls) were selected for epitope mapping. A total of 16 peptides and 
recombinant S1 and S2 proteins were predicted in this assay. JK2 and JK3 (recovered patients) display a pattern similar to our peptide vaccine, indicating that the vaccine has included all major epitopes (binding to C, D, H1, I1) (Figure 3).

A

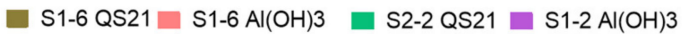

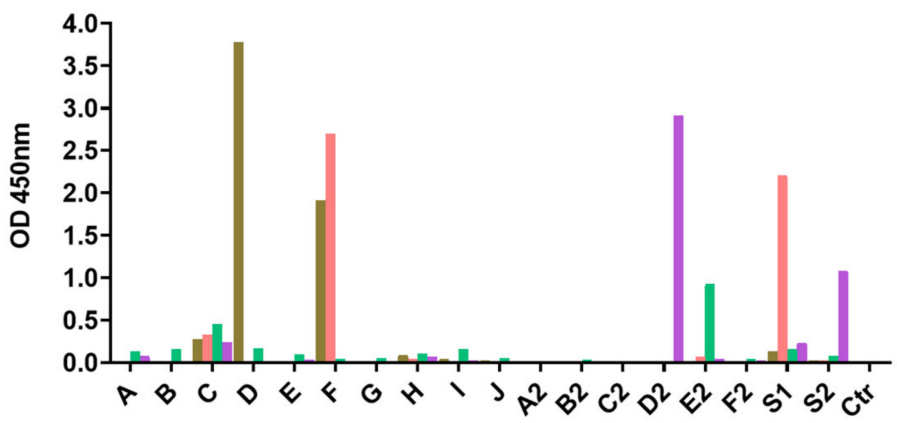

B

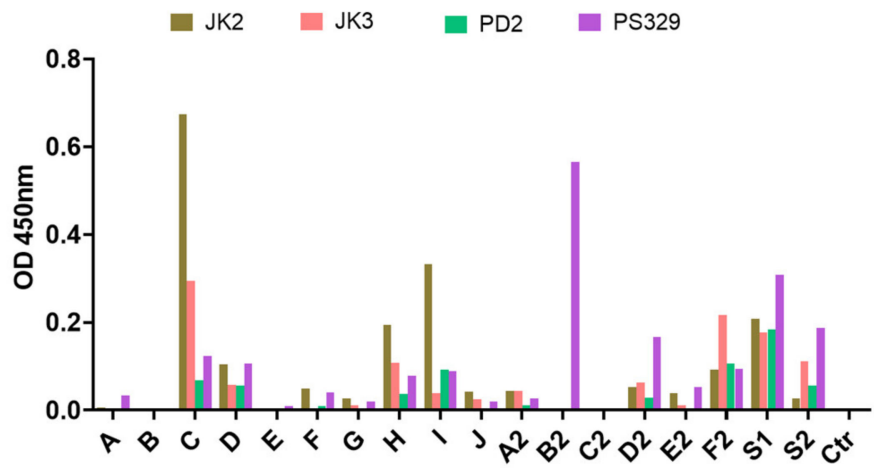

Figure 3. Epitope mapping results of vaccinated mouse plasma (A) versus human recovered plasma (B). Coating peptides A-J are peptides from the S1 protein, A2-F2 are peptides from the S2 protein. $\mathrm{S} 1$ is the recombinant S1 of the S protein and S2 is the recombinant S2 of the S protein. Ctr is a control peptide of human alpha-synuclein protein, which served as a negative control. Plasma was diluted at a 1:800 dilution with the sample, and ELISA results were shown in the graphs.

\subsection{The Duration of Antibody Response Post-Vaccination}

When examining the duration of the antibody response post-vaccination, $\mathrm{Al}(\mathrm{OH})_{3}$ appears to generate a longer antibody response than the QS21 adjuvant. Nonetheless, QS21 induced a higher antibody response to some antigens, such as the ones seen in peptide S1-B (Figure 4).

A

Peptide S1-B

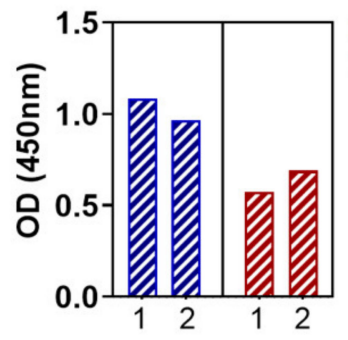

Mouse Plasma 1:200
B

Peptide S1-D

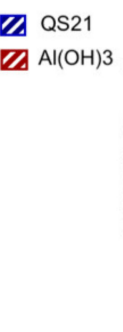

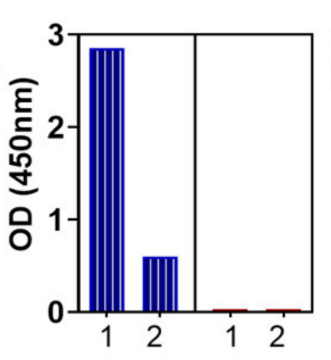

Mouse Plasma 1:800
C

\section{Peptide S1-F}

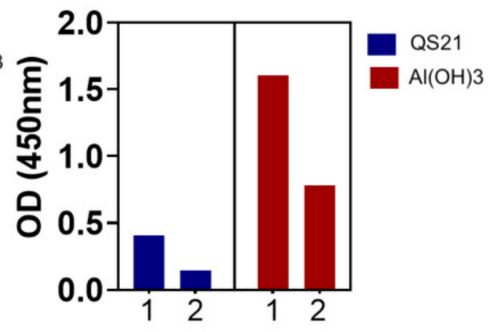

Mouse Plasma 1:800

Figure 4. Antibody duration between two adjuvants. The graphs above are the results of antibody testing via ELISA on blood from two time points (1 and 2): 1 is 10 days after the 6th vaccination and 2 is three months after $1 . \mathrm{Al}(\mathrm{OH})_{3}$ can generate a longer antibody response than QS21 $(\mathbf{B}, \mathbf{C})$. However, QS21 can induce a higher antibody response to some antigens, such as that seen in S1-B (A).

\subsection{Cell Population Analysis to Different Adjuvant Vaccines}

Mice blood samples were collected after the third vaccination of peptide mixture group 1 with different adjuvants to compare the B and T cell population difference. Flow cytometry assay was used to analyze the $\mathrm{T}$ and $\mathrm{B}$ cell population for each vaccine adjuvant. $\mathrm{CD} 3+$ and $\mathrm{CD} 8+\mathrm{T}$ cells (Figure $5 \mathrm{~A}, \mathrm{C}$ ) were significantly higher in $\mathrm{Al}(\mathrm{OH})_{3}$ groups than QS21 groups ( $p<0.05 ; \mathrm{N}=3$ per group). CD4+ T cells (Figure $5 \mathrm{~B}$ ) were also significantly higher in the $\mathrm{Al}(\mathrm{OH})_{3}$ adjuvant groups compared to both the QS21 and control groups $\left(p<0.05 ; \mathrm{n}=3\right.$ per group). Interestingly, the $\mathrm{B}$ cell population in the $\mathrm{Al}(\mathrm{OH})_{3}$ adjuvant group was significantly decreased when compared to the QS21 adjuvant group ( $N=3$ per 
group, $\alpha=0.05)$. These results imply that the $\mathrm{Al}(\mathrm{OH})_{3}$ adjuvant is ideal for obtaining the desired cellular response (Figure 5).

A

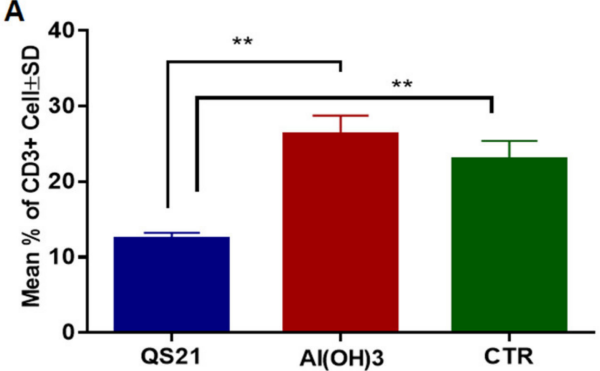

C

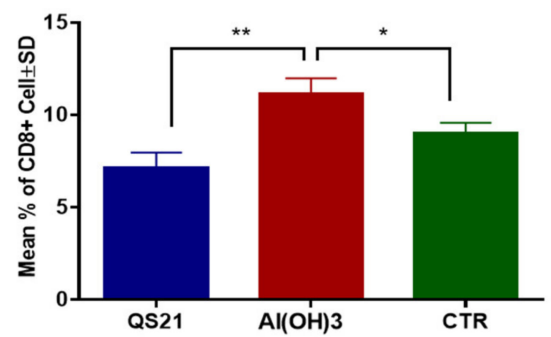

B

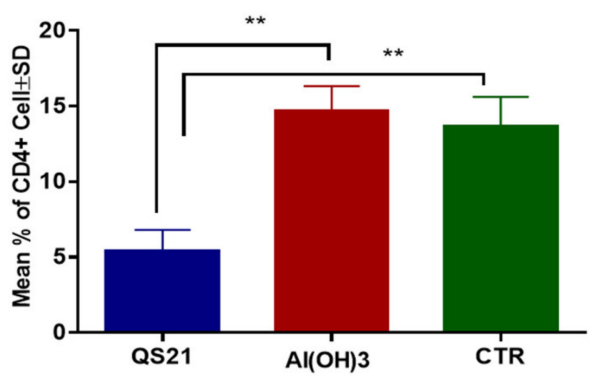

D

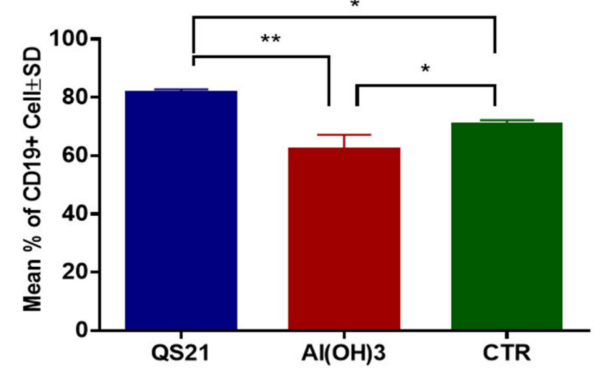

Figure 5. B and T cell population detection post vaccination. (A) CD3+ cell population; (B) CD4+ cell population; (C) CD8+ cell population; (D) CD19+ cell population. $\left({ }^{*} p<0.05,{ }^{* *} p<0.01, \mathrm{~N}=3\right.$ per group).

\subsection{Neutralizing Activity to Pseudovirus System}

The pseudovirus system in vitro was compared with recovered patient plasma to determine the neutralization potential of post-vaccinated mice plasma. The results showed that mice plasma had better neutralization function than human plasma in this system (Figure 6).

\subsection{The Immunoglobulin Isotyping of Plasma from Vaccinated Mice}

There are no differences in IgG levels among all three groups. IgM levels are higher in the vaccine group than control mice, indicating that the adjuvant-based peptide vaccine could not change the immunotype of the mice (Figure 7). 


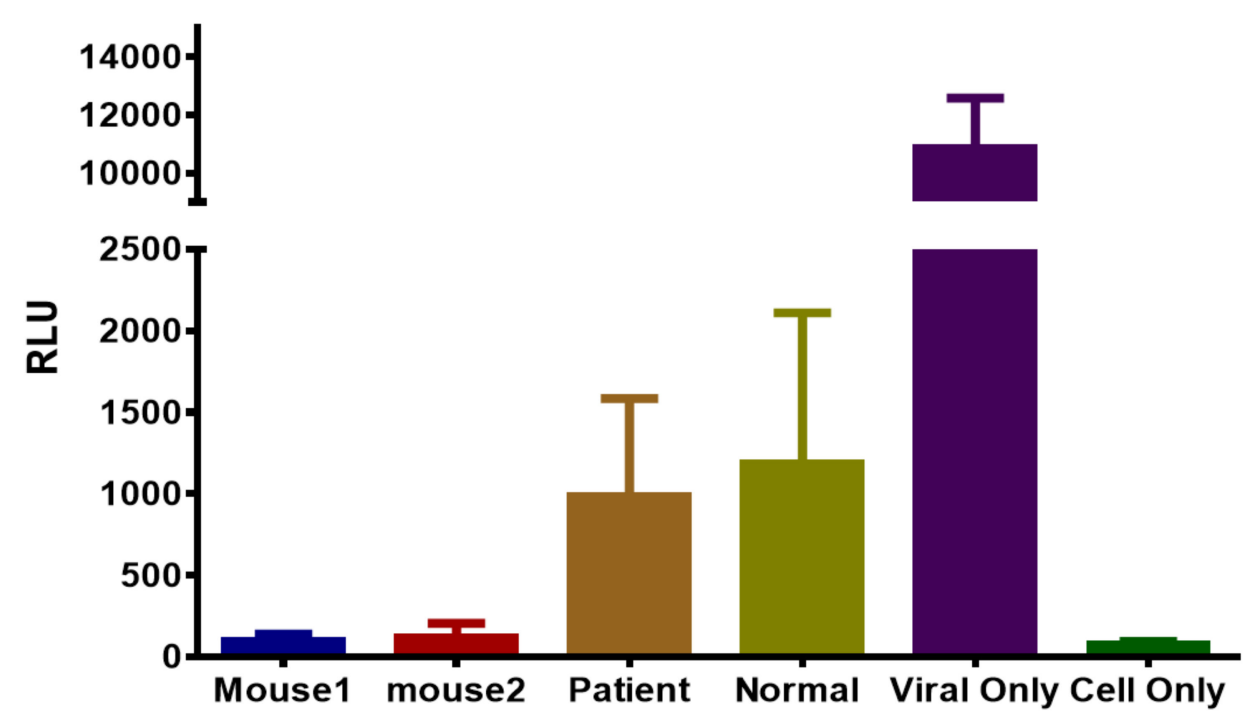

Figure 6. Results of neutralization assay of mouse and human plasma. Mouse1 was selected from the peptide mixture 1 group with the QS21 adjuvant; Mouse 2 was from the peptide mixture 1 group with the $\mathrm{Al}(\mathrm{OH})_{3}$ adjuvant; Patient is human plasma from a recovered COVID-19 infected patient; Normal is human negative plasma; Viral Only consists of the viral infected cells without adding plasma; Neg Ctr is cell only ( $\mathrm{N}=4$ per group).

A

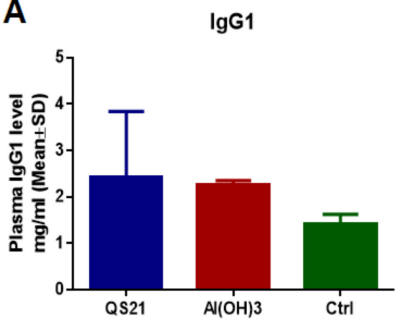

D

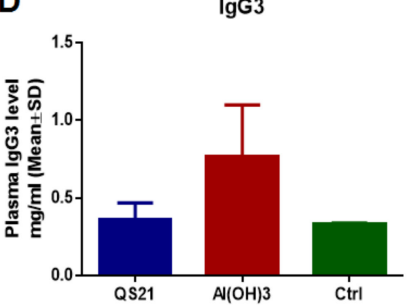

B

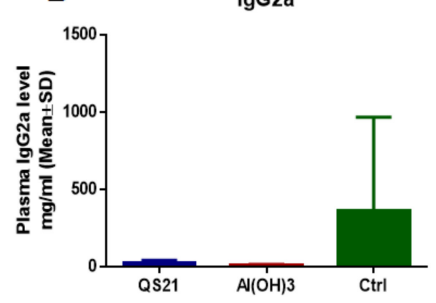

E

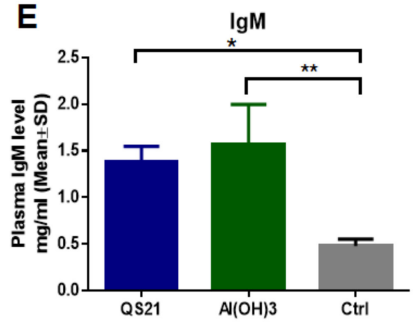

C

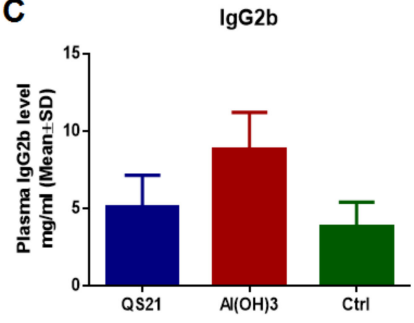

$\mathbf{F}$

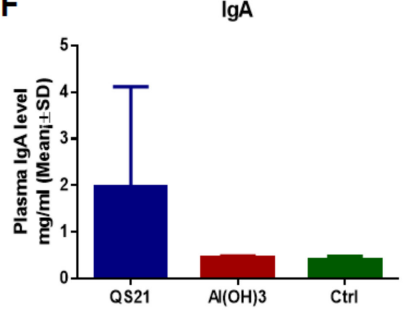

Figure 7. Ig Isotyping results of plasma from mice vaccinated with peptide mixture group 1. (A) IgG1 level; (B) IgG2a level; (C) IgG2b Level; (D) IgG3 Level; (E) IgM Level; (F) IgA Level; (the final dilution of mice plasma was at $1: 10,000)\left({ }^{*} p<0.05,{ }^{* *} p<0.01, \mathrm{~N}=3\right.$ per group).

\section{Discussion}

Vaccines are undeniably the most effective solution to stopping the spread of COVID19 , and several vaccines have already been distributed to contribute to this effort. Pfizer and Moderna have developed nanolipid-based mRNA particle vaccines, while Astrazeneca and Johnson \& Johnson have produced adenoviral vector-based DNA vaccines [26,64]. While these have become the most widely used vaccines to prevent COVID-19, other types of vaccines have also been developed, such as an inactivated whole viral particle vaccine (Kexing) and recombinant subunit vaccine (Novavax) [65-67]. Although the formulation of each vaccines varies, they all aim to block the binding of the S protein to ACE2 and inhibit viral entry into the host cell [1]. Virologists have proved that the COVID-19 virus surface has spike (S) proteins that can specifically bind to ACE2 through a receptor binding domain (RBD) [39]. The RBD on the $S$ protein of COVID-19 serves as the ligand for ACE2 
on the cell surface. It is important to note that most human organs produce the ACE2 protein [40], which may have contributed to the many deaths caused by COVID-19 that were also attributed to multiple organ failure [68].

The COVID-19 vaccines that are currently approved have been reported to have high rates of effectiveness, ranging from $66.3 \%$ to $95 \%$, and both $\mathrm{B}$ and $\mathrm{T}$ cell responses have been observed [69-78]. Moreover, no large-scale and severe adverse effects have been reported. However, long term monitoring is still necessary before an affirmative assessment can be made regarding vaccine safety.

The human immune system works diligently to protect the body from viruses [79]. During viral infection, immune cells produce large amounts of cytokines, which can result in cytokine storm syndrome [80]. Normally, a virus has a specific tissue receptor, meaning the virus can only infect certain tissues, while causing no harm to other tissues [81]. For instance, HIV targets the CD4 receptor, only infecting and killing CD4 T cells [82,83]. However, SARS-CoV-2 is markedly different from other viruses because it utilizes ACE2 receptors, and ACE2 is widely expressed by many types of cells across different organs [40]. ACE2 bound by the SARS-CoV-2 S protein can be considered a viral particle and will trigger an immune response [84]. This scenario complicates vaccine development because the abundance of ACE2 increases the likelihood of potential adverse responses caused by the vaccine and must therefore be carefully considered.

Most of the current vaccines use the $S$ protein as the antigen, and target for blocking viral entry by sealing RBD on S1 of COVID-19, which induces our immune system to attack cells that bind to the $S$ protein [21]. To induce an immune response, antigen-presenting cells (APCs) must uptake the S protein, process it, and then present it to CD4 or CD8 T cells [85]. Although this process is highly effective with other vaccines, it can be problematic for $S$ gene- or $S$ protein-based vaccines, since the $S$ protein will bind to the ACE2 of the host cell.

To combat the potential issues of current COVID-19 vaccines, our study uses peptides as opposed to whole $S$ protein to develop a vaccine for COVID-19. We selected 15 peptides for the whole S protein utilizing B and T cell epitope prediction methods. We have also used two of the most common adjuvants in our vaccine formula-QS21 and $\mathrm{Al}(\mathrm{OH})_{3}$-to enhance the immune response and tested this vaccine on a mouse model. The immunization results indicate that antibody production against each peptide varies with time and adjuvant used. In the QS21 adjuvant group, peptide B was the first antibody produced, followed by antibodies against peptides $\mathrm{C}, \mathrm{F}$, and $\mathrm{D}$. In the $\mathrm{Al}(\mathrm{OH})_{3}$ adjuvant group, antibodies against B, C, and F were detected at the same time after the second immunization, which was quicker than in the QS21 adjuvant group (Figure 1). Another major difference between the two adjuvants is that the $\mathrm{Al}(\mathrm{OH})_{3}$ group produced antibodies against peptide A much earlier than the QS21 group. Since it is imperative for the body to generate a sufficient $\mathrm{T}$ cell response to combat infectious diseases [86], the $\mathrm{T}$ and $\mathrm{B}$ cell population of each adjuvant was further analyzed. The results indicate that $\mathrm{Al}(\mathrm{OH})_{3}$ is the ideal adjuvant because it can induce a more robust T cell response than QS21 (Figure 5), although both adjuvants were able to induce an antibody response when tested using the ELISA assay. Since a high antibody titer does not always signify satisfactory protection, we also tested the protection of plasma with the pseudoviral system [87]. This showed that the plasma from the vaccinated mice can effectively neutralize viral entry (Figure 6). Another issue related to the anti-viral activity of plasma is determining how many epitopes are adequate to completely neutralize the viral entry that can be used as target sites for vaccine development [88]. To collect this information, epitope mapping with plasma from vaccinated mice and from infected patients was conducted. Epitope mapping revealed a similar antibody pattern from vaccinated mice to human samples, which confirmed that our epitope covered most B cell epitopes of the $S$ protein (Figure 2). Thus, our results demonstrated that development of a $S$ protein peptide-based vaccine is likely feasible to prevent COVID-19. 


\section{Conclusions}

The authors show that a peptide-based COVID-19 vaccine using $S$ protein peptides with the $\mathrm{Al}(\mathrm{OH})_{3}$ adjuvant generates a high antibody and $\mathrm{T}$ cell response. We also demonstrate that this peptide-based vaccine includes most major $B$ cell epitopes of the $S$ protein by comparing the serological antibody profiles of mice injected with our peptide-based vaccine with humans who were previously infected with COVID-19. Further investigation into peptide-based COVID-19 vaccines is warranted to evaluate important factors such as long-term efficacy.

Supplementary Materials: The following supporting information can be downloaded at: https: / / www.mdpi.com/article/10.3390/v14030449/s1, Table S1: Selection of SARS-CoV-2 peptides.

Author Contributions: Conceptualization, C.C.; Data curation, J.Y. and J.K.; Formal analysis, H.Y.; Investigation, H.Y., J.C., T.Z. and C.C.; Methodology, X.L. and C.C.; Resources, J.F. and R.-P.H.; Supervision, L.W., K.S. and C.C.; Visualization, J.C.; Writing-original draft, H.Y., J.C., T.Z. and J.K.; Writing-review and editing, H.Y., T.Z. and Y.B. All authors have read and agreed to the published version of the manuscript.

Funding: This project has been funded by the USF Research Foundation and the Florida High Tech Corridor Program.

Institutional Review Board Statement: Not applicable.

Informed Consent Statement: Not applicable.

Data Availability Statement: The data presented in this article are available on request from the corresponding author.

Conflicts of Interest: The authors declare no conflict of interest.

\section{References}

1. Zieneldien, T.; Kim, J.; Cao, J.; Cao, C. COVID-19 Vaccines: Current Conditions and Future Prospects. Biology 2021, 10, 960. [CrossRef] [PubMed]

2. Naik, A.Q.; Zafar, T.; Shrivastava, V.K. The Perspective of Coronavirus Disease Outbreak: Epidemiology, Transmission, and Possible Treatment. Vector Borne Zoonotic Dis. 2021, 21, 78-85. [CrossRef] [PubMed]

3. Kolahchi, Z.; De Domenico, M.; Uddin, L.Q.; Cauda, V.; Grossmann, I.; Lacasa, L.; Grancini, G.; Mahmoudi, M.; Rezaei, N. COVID-19 and Its Global Economic Impact. Adv. Exp. Med. Biol. 2021, 1318, 825-837. [CrossRef] [PubMed]

4. Cascella, M.; Mauro, I.; De Blasio, E.; Crispo, A.; Del Gaudio, A.; Bimonte, S.; Cuomo, A.; Ascierto, P.A. Rapid and Impressive Response to a Combined Treatment with Single-Dose Tocilizumab and NIV in a Patient with COVID-19 Pneumonia/ARDS. Medicina 2020, 56, 377. [CrossRef]

5. Mehta, M.; Shyh, G.I. A Review of Remdesivir for COVID-19: Data to Date. Cardiol. Rev. 2020, 28, 332-334. [CrossRef]

6. Zhang, C.; Huang, S.; Zheng, F.; Dai, Y. Controversial treatments: An updated understanding of the coronavirus disease 2019. J. Med. Virol. 2020, 92, 1441-1448. [CrossRef]

7. Guo, G.; Ye, L.; Pan, K.; Chen, Y.; Xing, D.; Yan, K.; Chen, Z.; Ding, N.; Li, W.; Huang, H.; et al. New Insights of Emerging SARS-CoV-2: Epidemiology, Etiology, Clinical Features, Clinical Treatment, and Prevention. Front. Cell Dev. Biol. 2020, 8, 410. [CrossRef]

8. $\quad$ Kreuzberger, N.; Hirsch, C.; Chai, K.L.; Tomlinson, E.; Khosravi, Z.; Popp, M.; Neidhardt, M.; Piechotta, V.; Salomon, S.; Valk, S.J.; et al. SARS-CoV-2-neutralising monoclonal antibodies for treatment of COVID-19. Cochrane Database Syst. Rev. 2021, 9, Cd013825. [CrossRef]

9. Liu, S.T.H.; Lin, H.M.; Baine, I.; Wajnberg, A.; Gumprecht, J.P.; Rahman, F.; Rodriguez, D.; Tandon, P.; Bassily-Marcus, A.; Bander J.; et al. Convalescent plasma treatment of severe COVID-19: A propensity score-matched control study. Nat. Med. 2020, 26, 1708-1713. [CrossRef]

10. Chowdhury, F.R.; Hoque, A.; Chowdhury, F.U.H.; Amin, M.R.; Rahim, A.; Rahman, M.M.; Yasmin, R.; Miah, M.T.; Kalam, M.A.; Rahman, M.S. Convalescent plasma transfusion therapy in severe COVID-19 patients-A safety, efficacy and dose response study: A structured summary of a study protocol of a phase II randomized controlled trial. Trials 2020, 21, 883. [CrossRef]

11. Lee, W.T.; Girardin, R.C.; Dupuis, A.P.; Kulas, K.E.; Payne, A.F.; Wong, S.J.; Arinsburg, S.; Nguyen, F.T.; Mendu, D.R.; FirpoBetancourt, A.; et al. Neutralizing Antibody Responses in COVID-19 Convalescent Sera. J. Infect. Dis. 2021, 223, 47-55. [CrossRef] [PubMed] 
12. Maor, Y.; Cohen, D.; Paran, N.; Israely, T.; Ezra, V.; Axelrod, O.; Shinar, E.; Izak, M.; Rahav, G.; Rahimi-Levene, N.; et al. Compassionate use of convalescent plasma for treatment of moderate and severe pneumonia in COVID-19 patients and association with IgG antibody levels in donated plasma. EClinicalMedicine 2020, 26, 100525. [CrossRef] [PubMed]

13. Duan, K.; Liu, B.; Li, C.; Zhang, H.; Yu, T.; Qu, J.; Zhou, M.; Chen, L.; Meng, S.; Hu, Y.; et al. Effectiveness of convalescent plasma therapy in severe COVID-19 patients. Proc. Natl. Acad. Sci. USA 2020, 117, 9490-9496. [CrossRef] [PubMed]

14. Jahanshahlu, L.; Rezaei, N. Monoclonal antibody as a potential anti-COVID-19. Biomed. Pharm. 2020, 129, 110337. [CrossRef]

15. Hinman, A. Eradication of vaccine-preventable diseases. Annu. Rev. Public Health 1999, 20, 211-229. [CrossRef]

16. Tamandjou Tchuem, C.R.; Andersson, M.I.; Wiysonge, C.S.; Mufenda, J.; Preiser, W.; Cleary, S. Prevention of hepatitis B mother-to-child transmission in Namibia: A cost-effectiveness analysis. Vaccine 2021, 39, 3141-3151. [CrossRef]

17. Safadi, R.; Khoury, T.; Saed, N.; Hakim, M.; Jamalia, J.; Nijim, Y.; Farah, N.; Nuser, T.; Natur, N.; Mahamid, M.; et al. Efficacy of Birth Dose Vaccination in Preventing Mother-to-Child Transmission of Hepatitis B: A Randomized Controlled Trial Comparing Engerix-B and Sci-B-Vac. Vaccines 2021, 9, 331. [CrossRef]

18. Brisson, M.; Kim, J.J.; Canfell, K.; Drolet, M.; Gingras, G.; Burger, E.A.; Martin, D.; Simms, K.T.; Bénard, É; Boily, M.C.; et al. Impact of HPV vaccination and cervical screening on cervical cancer elimination: A comparative modelling analysis in 78 low-income and lower-middle-income countries. Lancet 2020, 395, 575-590. [CrossRef]

19. Gottlieb, S.L.; Low, N.; Newman, L.M.; Bolan, G.; Kamb, M.; Broutet, N. Toward global prevention of sexually transmitted infections (STIs): The need for STI vaccines. Vaccine 2014, 32, 1527-1535. [CrossRef]

20. Amanat, F.; Krammer, F. SARS-CoV-2 Vaccines: Status Report. Immunity 2020, 52, 583-589. [CrossRef]

21. Chen, W.H.; Strych, U.; Hotez, P.J.; Bottazzi, M.E. The SARS-CoV-2 Vaccine Pipeline: An Overview. Curr. Trop. Med. Rep. 2020, 7, 61-64. [CrossRef] [PubMed]

22. Saif, L.J. Vaccines for COVID-19: Perspectives, Prospects, and Challenges Based on Candidate Sars, Mers, and Animal Coronavirus Vaccines. EMJ 2020, 20032, 1-7. [CrossRef]

23. Ahmed, S.F.; Quadeer, A.A.; McKay, M.R. Preliminary Identification of Potential Vaccine Targets for the COVID-19 Coronavirus (SARS-CoV-2) Based on SARS-CoV Immunological Studies. Viruses 2020, 12, 254. [CrossRef] [PubMed]

24. Yi, C.; Yi, Y.; Li, J. mRNA Vaccines: Possible Tools to Combat SARS-CoV-2. Virol. Sin. 2020, 35, 259-262. [CrossRef] [PubMed]

25. Voysey, M.; Clemens, S.A.C.; Madhi, S.A.; Weckx, L.Y.; Folegatti, P.M.; Aley, P.K.; Angus, B.; Baillie, V.L.; Barnabas, S.L.; Bhorat, Q.E.; et al. Safety and efficacy of the ChAdOx1 nCoV-19 vaccine (AZD1222) against SARS-CoV-2: An interim analysis of four randomised controlled trials in Brazil, South Africa, and the UK. Lancet 2021, 397, 99-111. [CrossRef]

26. Knoll, M.D.; Wonodi, C. Oxford-AstraZeneca COVID-19 vaccine efficacy. Lancet 2021, 397, 72-74. [CrossRef]

27. Jones, I.; Roy, P. Sputnik V COVID-19 vaccine candidate appears safe and effective. Lancet 2021, 397, 642-643. [CrossRef]

28. Burki, T.K. The Russian vaccine for COVID-19. Lancet Respir. Med. 2020, 8, e85-e86. [CrossRef]

29. Balakrishnan, V.S. The arrival of Sputnik V. Lancet Infect. Dis. 2020, 20, 1128. [CrossRef]

30. Johnson, J. A Randomized, Double-Blind, Placebo-Controlled Phase 3 Study to Assess the Efficacy and Safety of Ad26.COV2.S for the Prevention of SARS-CoV-2-Mediated COVID-19 in Adults Aged 18 Years and Older. 2020. Available online: https: / / www.jnj.com/coronavirus/ensemble-2-study-protocol (accessed on 24 November 2021).

31. Keech, C.; Albert, G.; Cho, I.; Robertson, A.; Reed, P.; Neal, S.; Plested, J.; Zhu, M.; Cloney-Clark, S.; Zhou, H.; et al. Phase 1-2 Trial of a SARS-CoV-2 Recombinant Spike Protein Nanoparticle Vaccine. N. Engl. J. Med. 2020, 383, 2320-2332. [CrossRef]

32. Singh, H.; Jakhar, R.; Sehrawat, N. Designing spike protein (S-Protein) based multi-epitope peptide vaccine against SARS COVID-19 by immunoinformatics. Heliyon 2020, 6, e05558. [CrossRef] [PubMed]

33. Kyriakidis, N.C.; López-Cortés, A.; González, E.V.; Grimaldos, A.B.; Prado, E.O. SARS-CoV-2 vaccines strategies: A comprehensive review of phase 3 candidates. NPJ Vaccines 2021, 6, 28. [CrossRef] [PubMed]

34. Li, F. Structure, Function, and Evolution of Coronavirus Spike Proteins. Annu. Rev. Virol. 2016, 3, 237-261. [CrossRef] [PubMed]

35. Jackson, C.B.; Farzan, M.; Chen, B.; Choe, H. Mechanisms of SARS-CoV-2 entry into cells. Nat. Rev. Mol. Cell Biol. 2021, 23, 3-20. [CrossRef] [PubMed]

36. Juraszek, J.; Rutten, L.; Blokland, S.; Bouchier, P.; Voorzaat, R.; Ritschel, T.; Bakkers, M.J.G.; Renault, L.L.R.; Langedijk, J.P.M. Stabilizing the closed SARS-CoV-2 spike trimer. Nat. Commun. 2021, 12, 244. [CrossRef] [PubMed]

37. Scialo, F.; Daniele, A.; Amato, F.; Pastore, L.; Matera, M.G.; Cazzola, M.; Castaldo, G.; Bianco, A. ACE2: The Major Cell Entry Receptor for SARS-CoV-2. Lung 2020, 198, 867-877. [CrossRef] [PubMed]

38. Huang, Y.; Yang, C.; Xu, X.F.; Xu, W.; Liu, S.W. Structural and functional properties of SARS-CoV-2 spike protein: Potential antivirus drug development for COVID-19. Acta Pharm. Sin. 2020, 41, 1141-1149. [CrossRef]

39. Shang, J.; Wan, Y.; Luo, C.; Ye, G.; Geng, Q.; Auerbach, A.; Li, F. Cell entry mechanisms of SARS-CoV-2. Proc. Natl. Acad. Sci. USA 2020, 117, 11727-11734. [CrossRef]

40. Hamming, I.; Timens, W.; Bulthuis, M.L.; Lely, A.T.; Navis, G.; van Goor, H. Tissue distribution of ACE2 protein, the functional receptor for SARS coronavirus. A first step in understanding SARS pathogenesis. J. Pathol. 2004, 203, 631-637. [CrossRef]

41. Bourgonje, A.R.; Abdulle, A.E.; Timens, W.; Hillebrands, J.L.; Navis, G.J.; Gordijn, S.J.; Bolling, M.C.; Dijkstra, G.; Voors, A.A.; Osterhaus, A.D.; et al. Angiotensin-converting enzyme 2 (ACE2), SARS-CoV-2 and the pathophysiology of coronavirus disease 2019 (COVID-19). J. Pathol. 2020, 251, 228-248. [CrossRef]

42. Mahase, E. COVID-19: What have we learnt about the new variant in the UK? BMJ 2020, 371, m4944. [CrossRef] 
43. Nagy, Á.; Pongor, S.; Győrffy, B. Different mutations in SARS-CoV-2 associate with severe and mild outcome. Int. J. Antimicrob. Agents 2021, 57, 106272. [CrossRef] [PubMed]

44. Iyengar, K.P.; Jain, V.K.; Ish, P. COVID-19 reinfection-An enigmatic public health threat. Monaldi Arch. Chest Dis. 2020, 90. [CrossRef] [PubMed]

45. Raghav, S.; Ghosh, A.; Turuk, J.; Kumar, S.; Jha, A.; Madhulika, S.; Priyadarshini, M.; Biswas, V.K.; Shyamli, P.S.; Singh, B.; et al. Analysis of Indian SARS-CoV-2 Genomes Reveals Prevalence of D614G Mutation in Spike Protein Predicting an Increase in Interaction with TMPRSS2 and Virus Infectivity. Front. Microbiol. 2020, 11, 594928. [CrossRef] [PubMed]

46. West, J.; Everden, S.; Nikitas, N. A case of COVID-19 reinfection in the UK. Clin. Med. 2021, 21, e52-e53. [CrossRef]

47. Iwasaki, A. What reinfections mean for COVID-19. Lancet Infect. Dis. 2021, 21, 3-5. [CrossRef]

48. Noh, J.Y.; Jeong, H.W.; Shin, E.C. SARS-CoV-2 mutations, vaccines, and immunity: Implication of variants of concern. Signal Transduct. Target. 2021, 6, 203. [CrossRef]

49. Klinman, D.M.; Klaschik, S.; Tomaru, K.; Shirota, H.; Tross, D.; Ikeuchi, H. Immunostimulatory CpG oligonucleotides: Effect on gene expression and utility as vaccine adjuvants. Vaccine 2010, 28, 1919-1923. [CrossRef]

50. Garçon, N.; Segal, L.; Tavares, F.; Van Mechelen, M. The safety evaluation of adjuvants during vaccine development: The AS04 experience. Vaccine 2011, 29, 4453-4459. [CrossRef]

51. Petrovsky, N.; Aguilar, J.C. Vaccine adjuvants: Current state and future trends. Immunol. Cell Biol. 2004, 82, 488-496. [CrossRef]

52. Orgogozo, J.M.; Gilman, S.; Dartigues, J.F.; Laurent, B.; Puel, M.; Kirby, L.C.; Jouanny, P.; Dubois, B.; Eisner, L.; Flitman, S.; et al. Subacute meningoencephalitis in a subset of patients with AD after Abeta42 immunization. Neurology 2003, 61, 46-54. [CrossRef] [PubMed]

53. Sasaki, S.; Tsuji, T.; Asakura, Y.; Fukushima, J.; Okuda, K. The search for a potent DNA vaccine against AIDS: The enhancement of immunogenicity by chemical and genetic adjuvants. Anticancer Res. 1998, 18, 3907-3915. [PubMed]

54. Tan, Z.; Zhou, T.; Zheng, H.; Ding, Y.; Xu, W. Malaria DNA vaccine gp96NTD-CSP elicits both CSP-specific antibody and CD8(+) T cell response. Parasitol. Res. 2015, 114, 2333-2339. [CrossRef] [PubMed]

55. Cox, K.S.; Clair, J.H.; Prokop, M.T.; Sykes, K.J.; Dubey, S.A.; Shiver, J.W.; Robertson, M.N.; Casimiro, D.R. DNA gag/adenovirus type 5 (Ad5) gag and Ad5 gag/Ad5 gag vaccines induce distinct T-cell response profiles. J. Virol. 2008, 82, 8161-8171. [CrossRef]

56. Kosinska, A.D.; Johrden, L.; Zhang, E.; Fiedler, M.; Mayer, A.; Wildner, O.; Lu, M.; Roggendorf, M. DNA prime-adenovirus boost immunization induces a vigorous and multifunctional T-cell response against hepadnaviral proteins in the mouse and woodchuck model. J. Virol. 2012, 86, 9297-9310. [CrossRef]

57. Polack, F.P.; Thomas, S.J.; Kitchin, N.; Absalon, J.; Gurtman, A.; Lockhart, S.; Perez, J.L.; Pérez Marc, G.; Moreira, E.D.; Zerbini, C.; et al. Safety and Efficacy of the BNT162b2 mRNA COVID-19 Vaccine. N. Engl. J. Med. 2020, 383, 2603-2615. [CrossRef]

58. Larché, M.; Wraith, D.C. Peptide-based therapeutic vaccines for allergic and autoimmune diseases. Nat. Med. 2005, 11, S69-S76. [CrossRef]

59. Li, W.; Joshi, M.D.; Singhania, S.; Ramsey, K.H.; Murthy, A.K. Peptide Vaccine: Progress and Challenges. Vaccines 2014, 2, 515-536. [CrossRef]

60. Reche, P.; Flower, D.R.; Fridkis-Hareli, M.; Hoshino, Y. Peptide-Based Immunotherapeutics and Vaccines 2015. J. Immunol. Res. 2015, 2015, 349049. [CrossRef]

61. Güven, E.; Duus, K.; Laursen, I.; Højrup, P.; Houen, G. Aluminum hydroxide adjuvant differentially activates the three complement pathways with major involvement of the alternative pathway. PLoS ONE 2013, 8, e74445. [CrossRef]

62. Majgaard Jensen, $\mathrm{O} . ; \mathrm{Koch}, \mathrm{C}$. On the effect of $\mathrm{Al}(\mathrm{OH})_{3}$ as an immunological adjuvant. APMIS 1988, 96, 257-264. [CrossRef] [PubMed]

63. Lacaille-Dubois, M.A. Updated insights into the mechanism of action and clinical profile of the immunoadjuvant QS-21: A review. Phytomedicine 2019, 60, 152905. [CrossRef] [PubMed]

64. Livingston, E.H.; Malani, P.N.; Creech, C.B. The Johnson \& Johnson Vaccine for COVID-19. JAMA 2021, 325, 1575. [CrossRef] [PubMed]

65. Sharma, O.; Sultan, A.A.; Ding, H.; Triggle, C.R. A Review of the Progress and Challenges of Developing a Vaccine for COVID-19. Front. Immunol. 2020, 11, 585354. [CrossRef]

66. Wadman, M.; Cohen, J. Novavax vaccine delivers 89\% efficacy against COVID-19 in UK-But is less potent in South Africa. Science 2021, 12, 2774.

67. Shinde, V.; Bhikha, S.; Hoosain, Z.; Archary, M.; Bhorat, Q.; Fairlie, L.; Lalloo, U.; Masilela, M.S.L.; Moodley, D.; Hanley, S.; et al Efficacy of NVX-CoV2373 COVID-19 Vaccine against the B.1.351 Variant. N. Engl. J. Med. 2021, 384, 1899-1909. [CrossRef]

68. Elezkurtaj, S.; Greuel, S.; Ihlow, J.; Michaelis, E.G.; Bischoff, P.; Kunze, C.A.; Sinn, B.V.; Gerhold, M.; Hauptmann, K.; IngoldHeppner, B.; et al. Causes of death and comorbidities in hospitalized patients with COVID-19. Sci. Rep. 2021, 11, 4263. [CrossRef]

69. Remmel, A. COVID vaccines and safety: What the research says. Nature 2021, 590, 538-540. [CrossRef]

70. Chagla, Z. The BNT162b2 (BioNTech/Pfizer) vaccine had 95\% efficacy against COVID-19 $\geq 7$ days after the 2nd dose. Ann. Intern. Med. 2021, 174, JC15. [CrossRef]

71. Hotez, P.J.; Nuzhath, T.; Callaghan, T.; Colwell, B. COVID-19 Vaccine Decisions: Considering the Choices and Opportunities. Microbes Infect. 2021, 23, 104811. [CrossRef] 
72. Mahase, E. COVID-19: Oxford vaccine is up to 90\% effective, interim analysis indicates. BMJ 2020, 371, m4564. [CrossRef] [PubMed]

73. Mahase, E. COVID-19: Russian vaccine efficacy is 91.6\%, show phase III trial results. BMJ 2021, 372, n309. [CrossRef] [PubMed]

74. Callaway, E. Coronavirus vaccines leap through safety trials-But which will work is anybody's guess. Nature 2020, 583, 669-670. [CrossRef]

75. Al-Kassmy, J.; Pedersen, J.; Kobinger, G. Vaccine Candidates against Coronavirus Infections. Where Does COVID-19 Stand? Viruses 2020, 12, 861. [CrossRef] [PubMed]

76. Meo, S.A.; Bukhari, I.A.; Akram, J.; Meo, A.S.; Klonoff, D.C. COVID-19 vaccines: Comparison of biological, pharmacological characteristics and adverse effects of Pfizer/BioNTech and Moderna Vaccines. Eur. Rev. Med. Pharm. Sci. 2021, 25, 1663-1669. [CrossRef]

77. Reynolds, C.J.; Pade, C.; Gibbons, J.M.; Butler, D.K.; Otter, A.D.; Menacho, K.; Fontana, M.; Smit, A.; Sackville-West, J.E.; Cutino-Moguel, T.; et al. Prior SARS-CoV-2 infection rescues B and T cell responses to variants after first vaccine dose. Science 2021, 372, 1418-1423. [CrossRef] [PubMed]

78. Sahin, U.; Muik, A.; Derhovanessian, E.; Vogler, I.; Kranz, L.M.; Vormehr, M.; Baum, A.; Pascal, K.; Quandt, J.; Maurus, D.; et al. COVID-19 vaccine BNT162b1 elicits human antibody and $\mathrm{T}_{\mathrm{H}} 1 \mathrm{~T}$ cell responses. Nature 2020, 586, 594-599. [CrossRef]

79. Koyama, S.; Ishii, K.J.; Coban, C.; Akira, S. Innate immune response to viral infection. Cytokine 2008, 43, 336-341. [CrossRef]

80. Hojyo, S.; Uchida, M.; Tanaka, K.; Hasebe, R.; Tanaka, Y.; Murakami, M.; Hirano, T. How COVID-19 induces cytokine storm with high mortality. Inflamm. Regen. 2020, 40,37. [CrossRef]

81. Baron, S.; Fons, M.; Albrecht, T. Viral Pathogenesis. In Medical Microbiology; Baron, S., Ed.; The University of Texas Medical Branch at Galveston: Galveston, TX, USA, 1996.

82. Rouse, B.T.; Sehrawat, S. Immunity and immunopathology to viruses: What decides the outcome? Nat. Rev. Immunol. 2010, 10, 514-526. [CrossRef]

83. Woodham, A.W.; Skeate, J.G.; Sanna, A.M.; Taylor, J.R.; Da Silva, D.M.; Cannon, P.M.; Kast, W.M. Human Immunodeficiency Virus Immune Cell Receptors, Coreceptors, and Cofactors: Implications for Prevention and Treatment. AIDS Patient Care STDS 2016, 30, 291-306. [CrossRef] [PubMed]

84. Shah, V.K.; Firmal, P.; Alam, A.; Ganguly, D.; Chattopadhyay, S. Overview of Immune Response During SARS-CoV-2 Infection: Lessons From the Past. Front. Immunol. 2020, 11, 1949. [CrossRef] [PubMed]

85. Burgdorf, S.; Kautz, A.; Böhnert, V.; Knolle, P.A.; Kurts, C. Distinct pathways of antigen uptake and intracellular routing in CD4 and CD8 T cell activation. Science 2007, 316, 612-616. [CrossRef] [PubMed]

86. Ledford, H. How 'killer' T cells could boost COVID immunity in face of new variants. Nature 2021, 590, 374-375. [CrossRef] [PubMed]

87. Sattentau, Q. Correlates of antibody-mediated protection against HIV infection. Curr. Opin. HIV AIDS 2008, 3, 368-374. [CrossRef]

88. Makhdoomi, M.A.; Khan, L.; Kumar, S.; Aggarwal, H.; Singh, R.; Lodha, R.; Singla, M.; Das, B.K.; Kabra, S.K.; Luthra, K. Evolution of cross-neutralizing antibodies and mapping epitope specificity in plasma of chronic HIV-1-infected antiretroviral therapy-naïve children from India. J. Gen. Virol. 2017, 98, 1879-1891. [CrossRef] 